\title{
Scutellarin protects against diabetic cardiomyopathy via inhibiting oxidative stress and inflammatory response in mice
}

\author{
Lijiao Xu ${ }^{1}$, Rongchang Chen ${ }^{1}$, Xu Zhang ${ }^{2}$, Yue Zhu ${ }^{2}$, Xiaoyu $\mathrm{Ma}^{2}$, Guibo Sun ${ }^{1}$, Xiaobo Sun ${ }^{1}$ \\ ${ }^{1}$ Institute of Medicinal Plant Development, Chinese Academy of Medical Science, Peking Union Medical College, Beijing, China; ${ }^{2}$ School of Life \\ and Environment Sciences, Harbin University of Commerce, Harbin, China \\ Contributions: (I) Conception and design: R Chen, X Sun; (II) Administrative support: X Ma, G Sun; (III) Provision of study materials or patients: X \\ Zhang, Y Zhu; (IV) Collection and assembly of data: L Xu; (V) Data analysis and interpretation: L Xu; (VI) Manuscript writing: All authors; (VII) \\ Final approval of manuscript: All authors. \\ Correspondence to: Rongchang Chen; Xiaobo Sun. Institute of Medicinal Plant Development, Chinese Academy of Medical Science, Peking Union \\ Medical College, No. 151, Malianwa North Road, Haidian District, Beijing 100094, China. \\ Email: chenrongchang456@126.com; sunxiaoboyzs@163.com.cn.
}

\begin{abstract}
Background Scutellarin $(\mathrm{Scu})$ shows both anti-inflammatory and antioxidant activities. The study investigates cardioprotective effects of Scu in mice with type 1 diabetes and the underlying molecular mechanism.

Methods: Streptozotocin (STZ) was used to induce diabetic cardiomyopathy (DCM) in C57BL/6 mice by intraperitoneal injection (i.p.). Normal and diabetic mice were divided into 6 groups: control, diabetic model group (DM), DM + Scu (5 mg/kg), DM + Scu (10 mg/kg), DM + Scu (20 mg/kg), DM + pioglitazone (Pio) $(10 \mathrm{mg} / \mathrm{kg})$. Scu was administered to the mice intraperitoneally and Pio was administrated by oral. Mice in control and DM groups were simply treated normal saline. Four weeks later, myocardial function, myocardial fibrosis, the levels inflammatory factors and oxidative stress were detected.
\end{abstract}

Results: Scu improved cardiac function and reduced heart injury in diabetic mice, which was indicated by increasing Left ventricular (LV) end-diastolic volume (LVVd), fractional shortening (FS), and ejection fraction (EF) levels and decreased pathological changes of heart. Scu inhibited the level of myocardial fibrosis by reducing the release of inflammatory cytokines and increasing activities of antioxidant enzymes. Further study showed that Scu inhibited the activation of nucleotide-binding oligomerization domain-like receptor with a pyrin domain 3 (NLRP3) and nuclear factor-kappa B (NF- $\mathrm{B})$ and activated phospho-protein kinase B (p-AKT), nuclear factor E2-related factor 2 (Nrf2), and heme oxygenase (HO-1).

Conclusions: Scu protects against DCM in STZ-induced diabetic mice by inhibiting oxidative stress and inflammatory responses and might be a potential therapeutic agent to treat DCM.

Keywords: Scutellarin (Scu); diabetic cardiomyopathy (DCM); anti-oxidative stress; anti-inflammatory

Submitted Nov 19, 2019. Accepted for publication Nov 20, 2020.

doi: $10.21037 /$ apm-19-516

View this article at: http://dx.doi.org/10.21037/apm-19-516

\section{Introduction}

Diabetes is a chronic, progressive disease and is expected to reach large epidemics over the next few decades. Diabetic cardiomyopathy (DCM) is a major complication of diabetes, which the prominent features are cardiac hypertrophy and fibrosis (1). Progressive of cardiac fibrosis will cause diastolic dysfunction in DCM, which leading to reduced myocardial contractility, and ultimately, heart failure (2). Although there are lots of studies on diabetes, the molecular mechanism of DCM remains poorly understood and further research in this area is urgently required.

The mechanisms of DCM are related with fibrosis and apoptosis. Oxidative stress plays a key role in the initial 
cellular pathogenesis of DCM. Biomarkers of oxidative stress were reported to be altered in DCM, including decrease of glutathione peroxidase (GSH-px), superoxide dismutase (SOD), advanced glycation end-products (AGEs), nicotinamide adenine dinucleotide phosphate (NADPH) activities and increase of reactive oxygen species (ROS) level, which causes cardiomyocyte injury by triggering apoptosis (3). Besides, in responds to longterm hyperglycemia, multiple pathological changes such as over expression of numerous inflammatory cytokines (e.g., tumor necrosis factor (TNF)- $\alpha$, interleukin-6 (IL-6) and monocyte chemoattractant protein (MCP)-1], induction of transforming growth factor- $\beta$ (TGF- $\beta$ ) that contributes to enhanced myocardial fibrosis and deposition of myocardial interstitial collagen (3). The cardiac inflammation and fibrosis will eventually induce irreversible structural remodeling and dysfunction of heart.

Inflammasomes are a group of cytosolic protein complexes, which consist of nucleotide-binding oligomerization domain-like receptor with a pyrin domain (NLRP), apoptosis-associated speck-like protein (ASC), and caspase- 1 and are formed to mediate host immune responses to microbial infection and cellular damage (4). Up to now, four inflammasomes have been identified: NLRP1, NLRP3, NLRC4, and absent in melanoma 2 (AIM2) (5). The NLRP3 inflammasome has been fully described and is related with a wide range of diseases, including infectious, autoimmune diseases, and auto-inflammatory (6). The NLRP3 interacts with ASC and then activates caspase-1, which induces maturation and secretion of interleukin (IL) $-1 \beta$ and IL-18. Previous studies found that NLRP3 inflammasome plays a key role in DCM and inhibition of NLRP3 limits the diabetes induced heart injury (7). So, NLRP3 inflammasome maybe an important target for preventing DCM.

Erigeron breviscapus (vant.) Hand-Mazz is a traditional Chinese herbal medicine and widely used in the clinic for the treatment of cerebral ischemia and cardiovascular diseases for a long time (8). Scutellarin (Scu, 4,5,6-trihydroxyflavone7 -glucuronide) is a bioactive flavonoid extracted from Erigeron breviscapus (vant.). Studies indicated that Scu shows various pharmacological properties, including alleviating cardiac fibrosis and decreasing the infarct size and dysfunction of rats with myocardial ischemia, suppressing cardiac hypertrophy, protecting against doxorubicin-induced acute cardiotoxicity (8-10). The molecular mechanism of its pharmacological effects may be related with antioxidation and anti-inflammatory activities $(11,12)$. However, the effect of Scu on DCM remains unknow. The present study was conducted to explore the protected effect of Scu on DCM and its underlying mechanism.

\section{Methods}

\section{Animals and experimental protocols}

Male C57/B6 mice weighing from 18 to $20 \mathrm{~g}$ were purchased from Beijing Vital River Laboratory Animal Technology Co., Ltd. (Beijing, China). The mice were housed under standard laboratory conditions (room temperature at $25 \pm 1{ }^{\circ} \mathrm{C}$ and humidity of $60 \%$ with a $12 \mathrm{~h}$ light/dark cycle). Briefly, diabetes was induced in the animals via intraperitoneal (i.p.) injection with freshly prepared streptozotocin (STZ) [dissolved in $0.1 \mathrm{~mol} / \mathrm{L}$ citrate acid buffer ( $\mathrm{pH} 4.5$ ), $50 \mathrm{mg} / \mathrm{kg}$ ] for 5 consecutive days. Control mice were injected with a vehicle solution $(0.1 \mathrm{~mol} / \mathrm{L}$ citrate acid buffer) ( $\mathrm{pH} 4.5)$. One week later, mice with hyperglycemia (3-h fasting blood glucose $\geq 250 \mathrm{mg} / \mathrm{dL}$ ) were considered diabetic. Then normal and diabetic mice were divided into 6 groups: control, diabetic model group (DM), $\mathrm{DM}+\mathrm{Scu}(5 \mathrm{mg} / \mathrm{kg}), \mathrm{DM}+\mathrm{Scu}(10 \mathrm{mg} / \mathrm{kg}), \mathrm{DM}+\mathrm{Scu}$ $(20 \mathrm{mg} / \mathrm{kg}), \mathrm{DM}+$ pioglitazone (Pio). Scu was administered to mice intraperitoneally and Pio was administrated by oral. Mice in control and DM groups were simply treated normal saline. Four weeks later, myocardial function, myocardial fibrosis, and the levels of inflammatory factors and oxidative stress relative factors were detected. All experimental procedures and protocols were conducted in accordance with the American Physiological Society "Guiding Principles in the Care and Use of Animals" and were approved by the Laboratory Animal Ethics Committee of the Institute of Medicinal Plant Development, Peking Union Medical College (No. 20181016). The mice were put to death by cervical vertebra dislocation after the experiment. The death of the mice was confirmed by observing the complete cessation of breathing and pupil dilation.

\section{Echocardiographic measurements}

After 4 weeks, cardiac function was analyzed using echocardiography. Briefly, after fasting for $12 \mathrm{~h}$, the mice were anesthetized using $4 \%$ chloral hydrate $(400 \mathrm{mg} / \mathrm{kg}$, i.p.), and their chests were shaved. M-mode echocardiography was performed using a Vevo $770^{\mathrm{TM}}$ High Resolution Imaging System (VisualSonics Inc., Canada). Fractional shortening (FS), ejection fraction (EF), Left ventricular (LV) end- 
diastolic volume (LVVd), and LV end-systolic volume (LVVs) were automatically calculated using an ultrasound machine.

\section{Determination of intracellular ROS}

Intracellular ROS generation was detected using a fluorometer. The ROS-sensitive dye 2,7-dichlorodihydrofluorescein diacetate (H2DCFDA) enters cells passively, is converted to dichlorofluorescin diacetate (DCFH), reacts with ROS, and ultimately forms the fluorescent product dichlorofluorescin (DCF). Heart tissues of mice were made into single cell suspension by methodology of enzymatic digestion. The cells were incubated with $20 \mathrm{mM}$ H2DCFDA for $30 \mathrm{~min}$. The fluorescence intensity was measured at $480 \mathrm{~nm}$ excitation and $530 \mathrm{~nm}$ emission using a fluorescence microplate reader.

Measurement levels of creatine kinase MB isoenzyme (CK$M B)$, lactate dehydrogenase (LDH), troponin (cTnI), and malondialdebyde (MDA) and catalase (CAT), SOD and GSH-Px in serum

Blood samples were obtained from the inner canthus using a capillary tube under chloral hydrate anesthesia. Samples were allowed to clot for $30 \mathrm{~min}$ and then centrifuged at $3,000 \times \mathrm{g}$ for $15 \mathrm{~min}$ at $4^{\circ} \mathrm{C}$. Myocardial injury markers, including $\mathrm{CK}-\mathrm{MB}, \mathrm{LDH}$, and $\mathrm{cTnI}$ in serum were measured using assay kits according to the manufacturer's protocols. The activities of SOD, MDA, GSH-Px, and CAT were detected using the corresponding kits (Nanjing Jiancheng Bioengineering Institute, Nanjing, China).

\section{HE and Masson staining}

Heart tissues were fixed in $10 \%$ formalin, dehydrated, and then embedded in paraffin. Paraffin-embedded tissues were sectioned to $5 \mu \mathrm{m}$ and were placed on glass slides, and then stained with hematoxylin and eosin (HE). Masson's trichrome staining were used to examine extracellular matrix deposition. The structure was observed under a light microscope (CKX41, 170 Olympus, Tokyo, Japan) by a pathologist blinded to the groups under study. In each group, at least 6 randomly selected sections were studied for the histological changes.

\section{Immunohistochemical analyses}

For immunohistochemistry, heart sections were dewaxed, rehydrated through graded ethanol washes, and incubated with $3 \%$ hydrogen peroxide for $10 \mathrm{~min}$. After antigen retrieval, the sections were obturated by incubation with bovine serum albumin for $60 \mathrm{~min}$. The sections were continuously incubated with the mouse anti-transforming growth factor- $\beta 1$ (TGF- $\beta 1$ ) and anti-collagen I (Col I) monoclonal antibody (Santa Cruz Biotechnology CA, USA). at $4{ }^{\circ} \mathrm{C}$ overnight, and then washed in phosphate-buffered saline (PBS) and incubated with the goat anti-mouse $\operatorname{IgG}$ secondary antibody for $1 \mathrm{~h}$ at room temperature. The sections were then stained with $0.5 \mathrm{~g} / \mathrm{L}$ diaminobenzidine for $8 \mathrm{~min}$, resulting in brown staining of the left ventricles of the hearts for viewing with an inverted microscope connected to a digital camera (CKX41,170 Olympus, Tokyo, Japan).

\section{ELISA for detection of $I L-6, I L-1 \beta, I L-18$, interferon- $\gamma$ (IFN- $\gamma)$, tumor necrosis factor- $\alpha(T N F-\alpha)$ and macrophage chemoattractant protein 1 (MCP-1) in serum}

Blood samples were obtained from the inner canthus using a capillary tube under chloral hydrate anesthesia. Samples were allowed to clot for $30 \mathrm{~min}$ and then centrifuged at $3,000 \times \mathrm{g}$ for $15 \mathrm{~min}$ at $4{ }^{\circ} \mathrm{C}$, and the supernatant was collected for subsequent measurements. The levels of TNF- $\alpha$, IL-1 $\beta$, IL-18, IFN- $\gamma$, IL- 6 and MCP- 1 were measured with a double-antibody sandwich ELISA according to the manufacturer's protocol (Beijing Baochen Biotechnology Co., Ltd. Beijing, China).

\section{Protein extraction and western blot analyses}

Briefly, total protein of heart tissues was extracted as previously described (13). After quantifying with bicinchoninic acid (BCA), the proteins were separated by $12 \%$ sodium dodecyl sulfate-polyacrylamide gel electrophoresis (SDS-PAGE) and transferred to nitrocellulose membranes. After blocking in $5 \%(\mathrm{w} / \mathrm{v})$ non-fat milk powder in tris-buffer containing $0.05 \%(\mathrm{v} / \mathrm{v})$ tween-20 (TBST) for $2 \mathrm{~h}$ at room temperature, the membranes were incubated with the appropriate primary antibodies (TGF $\beta 1$, COL1, IL18, IL1 $\beta$, NLRP3, Heme Oxygenase 1 (HO-1), protein kinase B (AKT), and P-AKT) (Santa Cruz Biotechnology CA, USA) at $4{ }^{\circ} \mathrm{C}$ overnight incubation. The membranes were then washed with TBST three times and incubated with secondary antibodies for $2 \mathrm{~h}$ at room temperature. Protein blots were developed using enhanced chemiluminescence solution. The protein 
Table 1 Effects of Scu on blood glucose, body weight, heart weight, and heart weight/body weight ratio in diabetic mice

\begin{tabular}{|c|c|c|c|c|c|c|}
\hline Physiological indexes & Control & DM & $\begin{array}{c}\mathrm{DM}+\mathrm{Scu} \\
5 \mathrm{mg} / \mathrm{kg}\end{array}$ & $\begin{array}{l}\mathrm{DM}+\mathrm{Scu} \\
10 \mathrm{mg} / \mathrm{kg}\end{array}$ & $\begin{array}{l}\mathrm{DM}+\mathrm{Scu} \\
20 \mathrm{mg} / \mathrm{kg}\end{array}$ & $\begin{array}{l}\mathrm{DM}+\mathrm{Pio} \\
10 \mathrm{mg} / \mathrm{kg}\end{array}$ \\
\hline Blood glucose (mM) & $8.12 \pm 1.02$ & $20.31 \pm 1.55^{\star}$ & $21.45 \pm 0.99$ & $20.68 \pm 1.71$ & $21.69 \pm 1.67$ & $20.05 \pm 1.33$ \\
\hline Body weight (g) & $29.45 \pm 1.32$ & $19.81 \pm 2.57^{*}$ & $20.34 \pm 2.35$ & $22.65 \pm 1.98$ & $23.04 \pm 2.41$ & $24.38 \pm 2.07$ \\
\hline Heart weight (g) & $0.144 \pm 0.003$ & $0.115 \pm 0.005^{\star}$ & $0.114 \pm 0.004$ & $0.120 \pm 0.003$ & $0.122 \pm 0.006$ & $0.125 \pm 0.004$ \\
\hline
\end{tabular}

Data are means $\pm \mathrm{SD} ; \mathrm{n}=12$ per group. *, $\mathrm{P}<0.05$ vs. cont group; ${ }^{,}, \mathrm{P}<0.05$ vs. DM group. $\mathrm{DM}$, diabetic model group.


Figure 1 Representative images of M-mode echocardiogram.

expression levels were visualized with Image Lab Software.

\section{Statistical analysis}

Data was presented as mean $\pm \mathrm{SD}$. The statistical significance of differences between groups were analyzed using one-way ANOVA followed by Student-NewmanKeuls post hoc test. GraphPad Prism software was used (GraphPad Software, Inc., La Jolla, CA, USA), and significant difference was accepted when $\mathrm{P}<0.05$.

\section{Results}

Effects of Scu on blood glucose, body weight, heart weight and heart weight/body weight ratio

As shown in Table 1, Compared with control group, mice in DM group showed higher glucose level $(\mathrm{P}<0.05)$, Scu had no effect on blood glucose of DM mice. Body weight (BW) and heart weight $(\mathrm{HW})$ of mice in DM group were lower than control group $(\mathrm{P}<0.05)$ and the $\mathrm{HW} / \mathrm{BW}$ ratio of $\mathrm{DM}$ mice were higher than control group $(\mathrm{P}<0.05)$. Although $\mathrm{BW}$ and $\mathrm{HW}$ of mice in Scu treatment groups showed a dose-dependent elevation compared to DM group, there has no significant differences. Scu decreased HW/BW ratio significantly at 10 and $20 \mathrm{mg} / \mathrm{kg}$ compared DM group $(\mathrm{P}<0.05)$.

\section{Effects of Scu on heart function of diabetic mice}

We measured cardiac parameters using M-mode echocardiography to investigate the protective effect of Scu on the cardiac function of diabetic mice (Figure 1). Compared with control group, EF, FS, and LVVd significantly decreased in DM group $(\mathrm{P}<0.05)$. However, compared with control group, Scu decreased EF and LVVd significantly at 10 and $20 \mathrm{mg} / \mathrm{kg}(\mathrm{P}<0.05)$ and reduced FS significantly at $20 \mathrm{mg} / \mathrm{kg}(\mathrm{P}<0.05)$, which proved that $\mathrm{Scu}$ could improve heart function of diabetic mice. However, no difference between groups existed as far as LVVs was concerned (Table 2). 
Table 2 Effects of Scu on left ventricular functions in diabetic mice

\begin{tabular}{|c|c|c|c|c|c|c|}
\hline $\begin{array}{l}\text { Myocardial } \\
\text { contractility indexes }\end{array}$ & Cont & DM & $\begin{array}{l}\mathrm{DM}+\mathrm{Scu} \\
5 \mathrm{mg} / \mathrm{kg}\end{array}$ & $\begin{array}{l}\mathrm{DM}+\mathrm{Scu} \\
10 \mathrm{mg} / \mathrm{kg}\end{array}$ & $\begin{array}{l}\mathrm{DM}+\mathrm{Scu} \\
20 \mathrm{mg} / \mathrm{kg}\end{array}$ & $\begin{array}{l}\mathrm{DM}+\mathrm{Pio} \\
10 \mathrm{mg} / \mathrm{kg}\end{array}$ \\
\hline EF\% & $76.91 \pm 4.13$ & $54.23 \pm 3.39^{\star}$ & $58.49 \pm 5.28$ & $60.88 \pm 4.42^{\#}$ & $70.13 \pm 3.96^{\#}$ & $71.61 \pm 5.18^{\#}$ \\
\hline $\operatorname{LVVd}(\mu \mathrm{L})$ & $92.55 \pm 5.35$ & $52.05 \pm 5.48^{\star}$ & $61.61 \pm 5.73^{\star}$ & $63.00 \pm 8.90^{\#}$ & $74.87 \pm 11.01^{\#}$ & $77.34 \pm 7.81^{\#}$ \\
\hline LVVs $(\mu \mathrm{L})$ & $43.94 \pm 7.80$ & $22.63 \pm 3.35^{\star}$ & $22.04 \pm 2.77$ & $26.10 \pm 5.98$ & $32.82 \pm 6.66^{\#}$ & $35.58 \pm 4.22^{\#}$ \\
\hline
\end{tabular}

Data are means $\pm \mathrm{SD} ; \mathrm{n}=6$ per group. *, $\mathrm{P}<0.05$ vs. cont group; *, $\mathrm{P}<0.05$ vs. DM group. DM, diabetic model group; LVVd, LV end-diastolic volume; LVS, LV end-systolic volume; FS, fractional shortening; EF, ejection fraction was automatically calculated by the ultrasound machine.

\section{Effects of Scu on cardiac injury of diabetic mice}

As shown in Figure 2A, HE staining of the heart tissues in control group showed regular myocardial fibers and normal morphology of cardiac myocytes. However, myocardial tissue in diabetic model group displayed grievous pathogenic structural changes and remodeling compared to the control group, especially characterized by disordered cellular structures of cardiomyocytes and hypertrophic myocardium. Scu treatment alleviated a majority of those pathologic characteristics. LDH, cTnI, and CK are three important indicators of cardiac injury. As shown in Figure 2B,C,D, the serum levels of LDH, CK-MB, and cTnI significantly increased in DM group $(\mathrm{P}<0.05)$. Compared with $\mathrm{DM}$ group, Scu decreased levels of LDH and cTnI at 5,10, and $20 \mathrm{mg} / \mathrm{kg}$ and inhibited activity of CK-MB at 10 and $20 \mathrm{mg} / \mathrm{kg}(\mathrm{P}<0.05)$. However, there has no differences between $\mathrm{Scu}(20 \mathrm{mg} / \mathrm{kg})$ group and Pio group.

\section{Effects of Scu on myocardial fibrosis of diabetic mice}

Masson's trichrome staining was performed to detected fibrosis and collagen content in diabetic hearts (Figure 3A). The quantitative analysis demonstrated the obvious collagen deposition in the hearts of the DM mice $(\mathrm{P}<0.05)$, and was prevented significantly by Scu treatment $(\mathrm{P}<0.05)$ (Figure $3 B$ ). We further performed immunohistochemical staining to test the expressions of Col I and TGF- $\beta 1$ in heart tissues. Compared to the control group, the expressions of $\mathrm{Col} \mathrm{I}$ and TGF- $\beta 1$ in heart tissues of DM group increased significantly $(\mathrm{P}<0.05)$, which were reduced by $\mathrm{Scu}$ treatment at 10 and $20 \mathrm{mg} / \mathrm{kg}(\mathrm{P}<0.05)$ (Figure 4).

\section{Effects of Scu on ROS level and activities of antioxidant enzymes in diabetic mice}

To test if the protective effects of Scu against DCM were related to its antioxidative activity, we measured the oxidative stress associated parameters in serum. We found that mice in DM group showed significant decrease in SOD, CAT, and GSH-Px activities and increase in MDA and ROS production $(\mathrm{P}<0.05)$, which were significantly ameliorated by Scu treatment at 10 and $20 \mathrm{mg} / \mathrm{kg}(\mathrm{P}<0.05)$ (Table 3). These results indicated that Scu can increase the endogenous antioxidant capacity and alleviate oxidative stress.

\section{Effects of Scu on proinflammatory cytokines production in diabetic mice}

The levels of proinflammatory cytokines in serum of diabetic mice was determined using ELISA kits. Compared with control group, the levels of TNF- $\alpha$, IL-1 $\beta$, IL-18, IFN- $\gamma$, IL- 6 and MCP- 1 in serum of diabetic mice increased significantly $(\mathrm{P}<0.05)$. Compared with $\mathrm{DM}$ group, Scu decreased levels of IL-1 $\beta$, IFN- $\gamma$, IL-6 and MCP-1 at 10 and $20 \mathrm{mg} / \mathrm{kg}$ significantly $(\mathrm{P}<0.05)$. Besides, Scu decreased levels of TNF- $\alpha$ and IL-18 at 5,10 , and $20 \mathrm{mg} / \mathrm{kg}$ significantly $(\mathrm{P}<0.05)($ Table 4).

\section{Scu treatment inbibited NLRP3 signaling patbway in diabetic mice}

Western blot showed that the expression of IL-1 $1 \beta$, IL-18 and NLRP 3 increased in heart tissues of diabetic mice compared with control group $(\mathrm{P}<0.05)$. Compared with DM group, Scu decreased the level of IL- $1 \beta$ at 10 and $20 \mathrm{mg} / \mathrm{kg}$ and reduced levels of IL-18 and NLRP3 at 5, 10, and $20 \mathrm{mg} / \mathrm{kg}$ significantly $(\mathrm{P}<0.05)$. These results indicated that Scu may remitted cardiac inflammation in diabetic mice by inhibiting activation of NLRP3 inflammasome. Besides, compared with control group, the protein expression levels of TGF- $\beta 1$ and Col I in DM group 
A
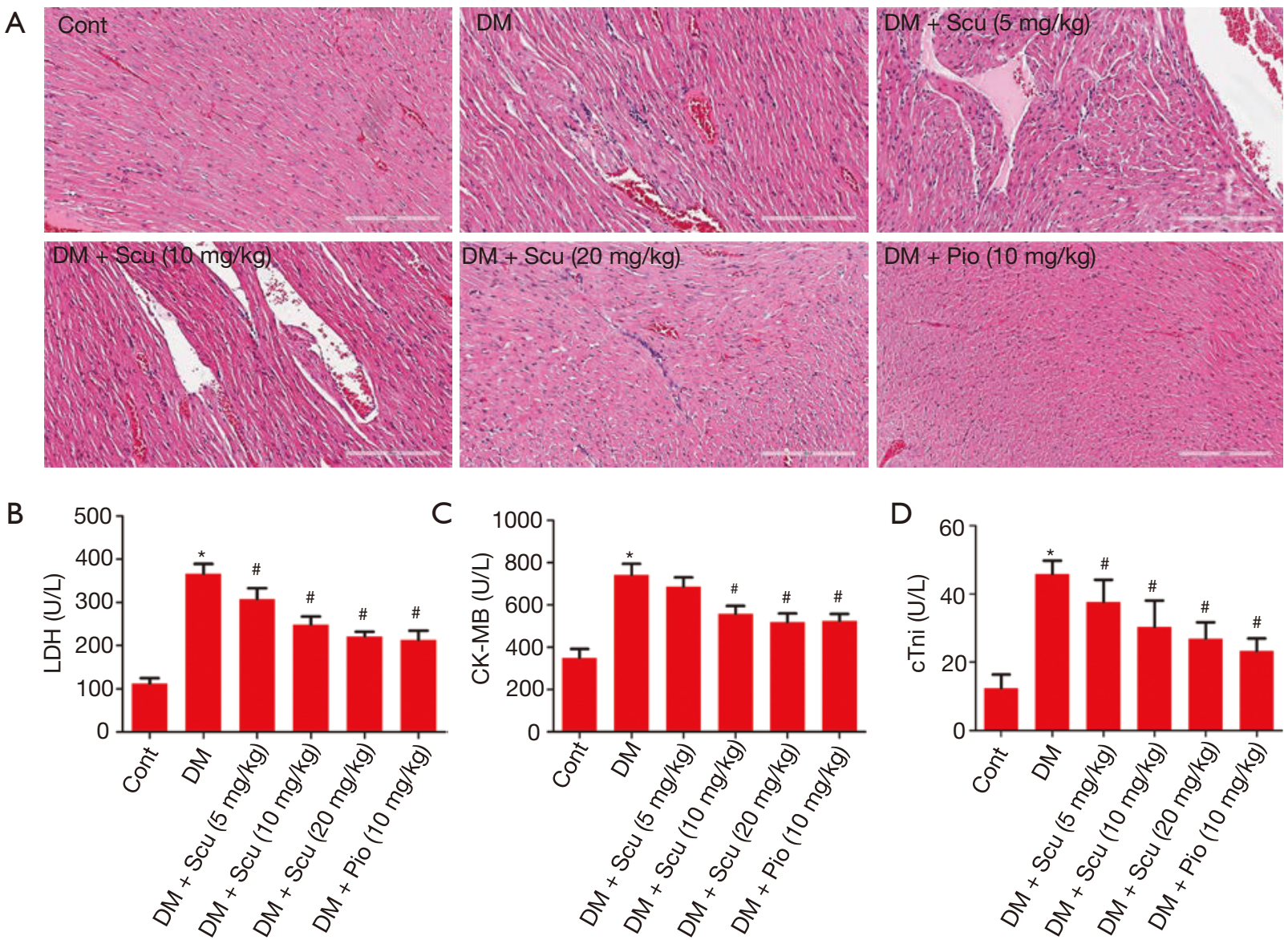

Figure 2 Effects of Scu on heart injury in DM mice. (A) Histological changes in mice hearts were measured by HE staining $(\times 100)$. Effects of Scu on activities of LDH (B), CK-MB (C), and AST (D) in serum of DM mice. Data are means \pm SD; $\mathrm{n}=12$ per group. * $\mathrm{P}<0.05$ s. cont group; ${ }^{\prime}, \mathrm{P}<0.05$ vs. DM group.

increased significantly $(\mathrm{P}<0.05)$ and were inhibited by $\mathrm{Scu}$ treatment $(\mathrm{P}<0.05)$, which was consistent with the results of immunohistochemical staining (Figure 5).

\section{Scu treatment inhibited NF- $\boldsymbol{\text { K B }}$ translocation, activated Nvf2/HO-1 patbway and AKT phosphorylation in diabetic mice}

Previous study found that NF- $\kappa \mathrm{B}$ can regulate activation of NLRP3 inflammasome. We proved that NF- $\kappa \mathrm{B}$ nuclear translocation increased significantly in heart tissues of diabetic mice $(\mathrm{P}<0.05)$, which were decreased by Scu treatment at 10 and $20 \mathrm{mg} / \mathrm{kg}(\mathrm{P}<0.05)$ (Figure 6). $\mathrm{Nrf} 2$ is a member of the basic leucine zipper transcription factor family and is responsible for upregulating transcriptional antioxidant proteins and phase II detoxifying enzymes. We evaluated the expression of Nrf2 in heart tissues and found that the nuclear Nrf2 expression in DM group increased significantly compared with control group $(\mathrm{P}<0.05)$. Compared with the DM group, Scu treatment further increase the nuclear Nrf2 expression significantly $(\mathrm{P}<0.05)$. We then examined the protein levels of HO-1, which is well-known target gene of $\mathrm{Nrf2}$. In accordance with the change in $\mathrm{Nrf2}$, the protein expression of HO-1 was moderately increased in $\mathrm{DM}$ group and significantly increased in Scu $(10,20 \mathrm{mg} / \mathrm{kg})$ treated mice $(\mathrm{P}<0.05)$ (Figure 6). Phosphorylation of AKT decreased significantly in DM group compared with control $(\mathrm{P}<0.05)$, which was prevented by Scu treatment at 10 and $20 \mathrm{mg} / \mathrm{kg}(\mathrm{P}<0.05)$ (Figure 6).

\section{Discussion}

In the present study, we found that Scu improved 
A
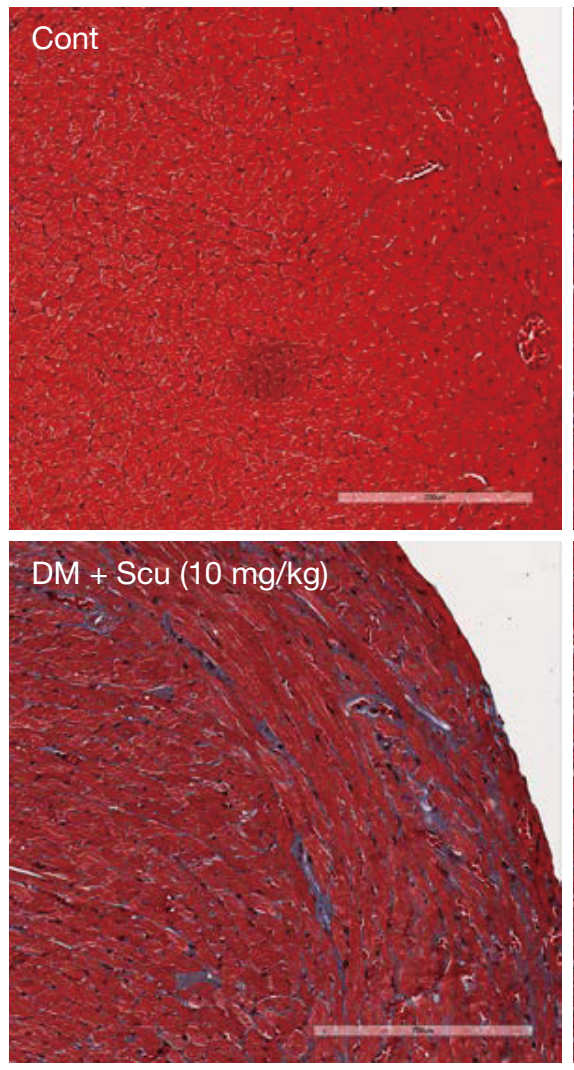
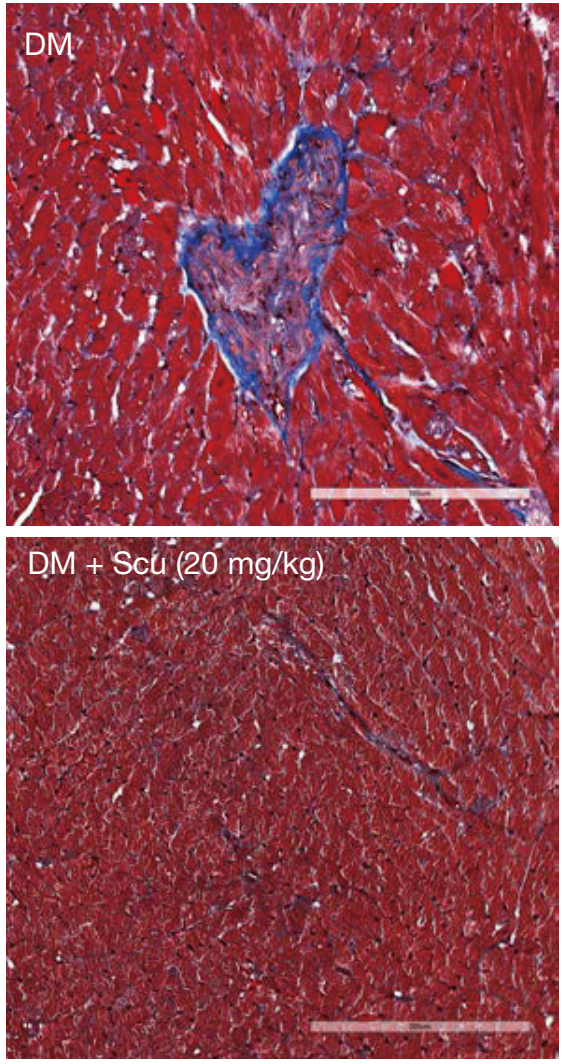


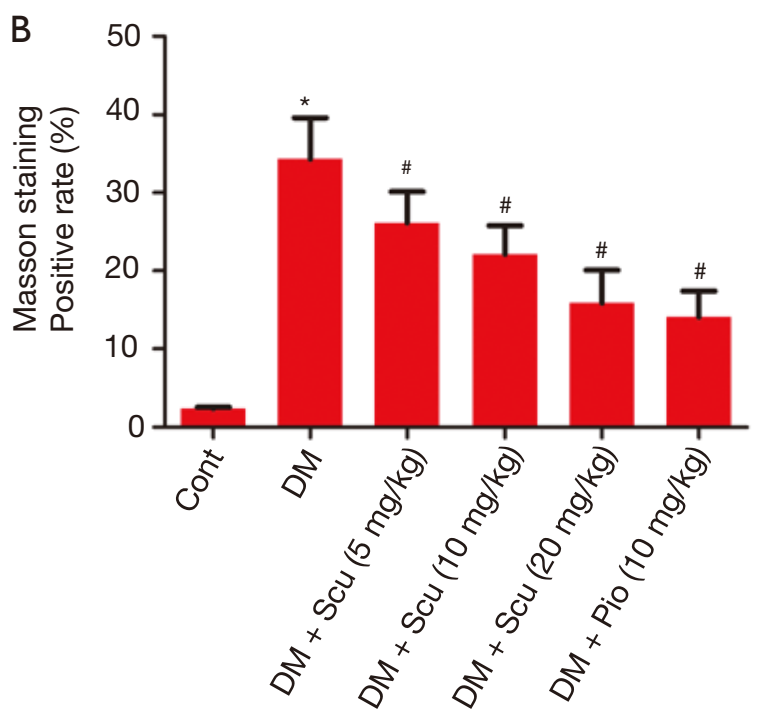

Figure 3 Scu attenuates diabetes-induced cardiac fibrosis. (A) Representative Masson's trichrome staining $(\times 100)$. (B) Quantitative analysis of Masson's trichrome staining to evaluate myocardial fibrosis. Data are means $\pm \mathrm{SD} ; \mathrm{n}=12$ per group. ${ }^{*}, \mathrm{P}<0.05$ vs. control group; ${ }^{\#}, \mathrm{P}<0.05$ vs. DM group.

myocardial contractile function, protected against heart injury and fibrosis, and inhibited oxidative stress and inflammation response in STZ-induced diabetic mice,

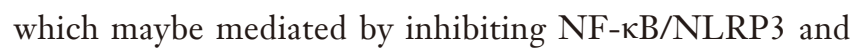
activating AKT and Nrf2. Our study showed that Scu might be a potential therapeutic agent to treat DCM. 
A



B

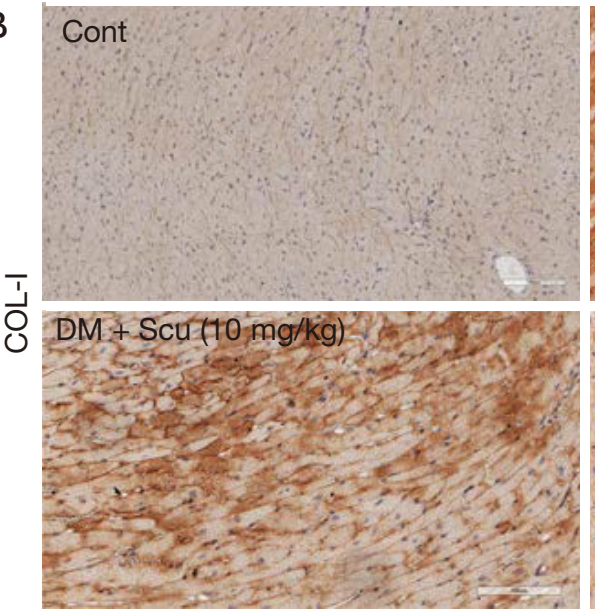

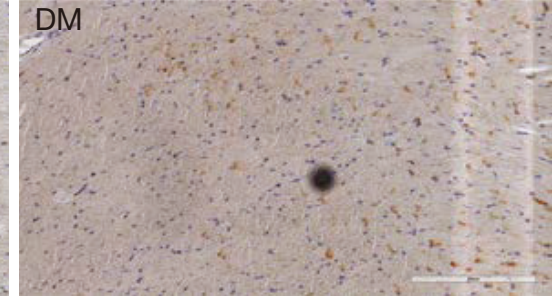
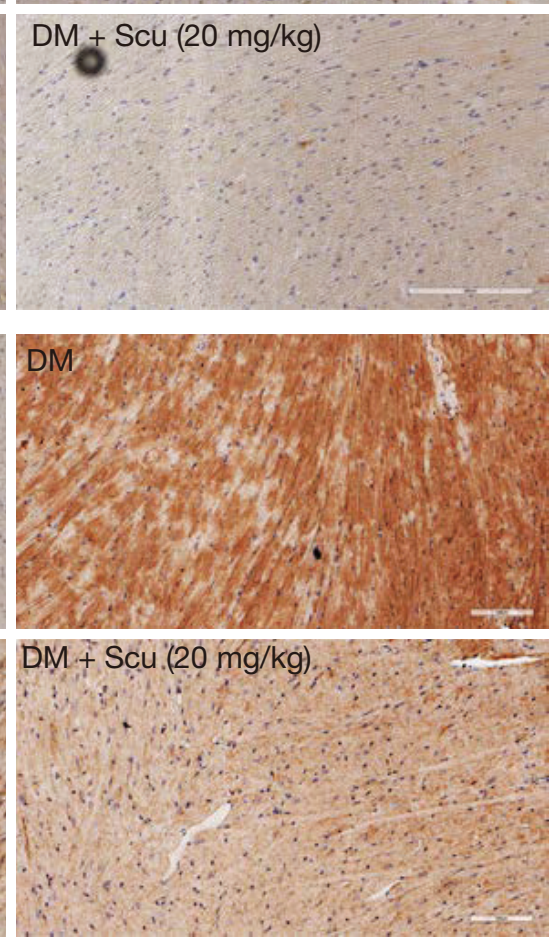


C


Figure 4 Effects of Scu on the levels of TGF $\beta 1$ and COL1 in cardiac tissues of mice. The hearts were harvested and sectioned for immunohistochemistry. $(\mathrm{A}, \mathrm{C})$ TGF $\beta 1$ and $(\mathrm{B}, \mathrm{D})$ COL 1-positive cells were examined under a microscope $(\times 100)$. Data are means $\pm \mathrm{SD}$; $\mathrm{n}=12$ per group. *, $\mathrm{P}<0.05$ vs. control group; ${ }^{*}, \mathrm{P}<0.05$ vs. $\mathrm{DM}$ group. 
Table 3 Effects of Scu on GSH-Px, SOD, CAT, and MDA activities in serum of diabetic mice

\begin{tabular}{lcccccc}
\hline $\begin{array}{l}\text { Target } \\
\text { enzymes }\end{array}$ & Cont & DM & $\begin{array}{c}\text { DM + Scu } \\
5 \mathrm{mg} / \mathrm{kg}\end{array}$ & $\begin{array}{c}\mathrm{DM}+\mathrm{Scu} \\
10 \mathrm{mg} / \mathrm{kg}\end{array}$ & $\begin{array}{c}\mathrm{DM}+\mathrm{Scu} \\
20 \mathrm{mg} / \mathrm{kg}\end{array}$ & $\begin{array}{c}\mathrm{DM}+\mathrm{Pio} \\
10 \mathrm{mg} / \mathrm{kg}\end{array}$ \\
\hline SOD (U/L) & $36.84 \pm 2.65$ & $24.37 \pm 2.23^{*}$ & $25.66 \pm 3.88$ & $29.38 \pm 2.41^{\#}$ & $31.46 \pm 3.81^{\#}$ & $28.88 \pm 2.23^{\#}$ \\
CAT (U/L) & $6.98 \pm 0.82$ & $3.55 \pm 0.47^{*}$ & $3.84 \pm 0.37$ & $4.57 \pm 0.44^{\#}$ & $4.83 \pm 0.46^{\#}$ & $4.62 \pm 0.55^{\#}$ \\
GSH-PX (U/L) & $42.03 \pm 3.55$ & $27.43 \pm 2.75^{*}$ & $32.74 \pm 4.01$ & $36.31 \pm 3.35^{\#}$ & $38.70 \pm 4.10^{\#}$ & $38.01 \pm 3.22^{\#}$ \\
MDA (U/L) & $13.95 \pm 1.65$ & $27.18 \pm 1.28^{*}$ & $25.46 \pm 2.79$ & $21.84 \pm 1.35^{\#}$ & $18.78 \pm 1.85^{\#}$ & $20.36 \pm 1.91^{\#}$ \\
\hline
\end{tabular}

Data are means $\pm \mathrm{SD} ; \mathrm{n}=12$ per group. * $\mathrm{P}<0.05$ vs. cont group; " $\mathrm{P}<0.05$ vs. DM group. DM, diabetic model group.

Table 4 Effects of Scu on the levels of proinflammatory cytokines in serum of diabetic mice

\begin{tabular}{lcccccc}
\hline $\begin{array}{l}\text { Inflammatory } \\
\text { factors }\end{array}$ & Cont & DM & $\begin{array}{c}\mathrm{DM}+\mathrm{Scu} \\
5 \mathrm{mg} / \mathrm{kg}\end{array}$ & $\begin{array}{c}\mathrm{DM}+\mathrm{Scu} \\
10 \mathrm{mg} / \mathrm{kg}\end{array}$ & $\begin{array}{c}\mathrm{DM}+\mathrm{Scu} \\
20 \mathrm{mg} / \mathrm{kg}\end{array}$ & $\begin{array}{c}\mathrm{DM}+\mathrm{Pio} \\
10 \mathrm{mg} / \mathrm{kg}\end{array}$ \\
\hline $\mathrm{IL}-18(\mathrm{pg} / \mathrm{mL})$ & $253.09 \pm 27.24$ & $505.59 \pm 37.85^{*}$ & $368.72 \pm 34.54^{\#}$ & $312.60 \pm 29.96^{\#}$ & $303.60 \pm 34.55^{\#}$ & $294.33 \pm 33.66^{\#}$ \\
$\mathrm{IL}-1 \beta(\mathrm{ng} / \mathrm{L})$ & $7.33 \pm 1.02$ & $23.40 \pm 2.27^{*}$ & $21.91 \pm 2.46$ & $19.76 \pm 1.15^{\#}$ & $14.30 \pm 2.58^{\#}$ & $12.65 \pm 2.31^{\#}$ \\
TNF- $\alpha(\mathrm{ng} / \mathrm{L})$ & $109.38 \pm 15.99$ & $406.61 \pm 26.44^{*}$ & $316.17 \pm 21.72^{\#}$ & $297.33 \pm 20.93^{\#}$ & $213.10 \pm 18.50^{\#}$ & $205.40 \pm 13.14^{\#}$ \\
IL-6 $(\mathrm{pg} / \mathrm{mL})$ & $6.33 \pm 0.56$ & $173.98 \pm 10.77^{*}$ & $165.21 \pm 13.62$ & $143.19 \pm 9.98^{\#}$ & $84.82 \pm 6.85^{\#}$ & $77.41 \pm 6.38^{\#}$ \\
$\mathrm{MCP}-1(\mathrm{ng} / \mathrm{mL})$ & $5.22 \pm 0.45$ & $56.39 \pm 4.09^{*}$ & $54.82 \pm 4.27$ & $41.08 \pm 2.10^{\#}$ & $35.89 \pm 3.43^{\#}$ & $32.20 \pm 4.15^{\#}$ \\
$\mathrm{IFN}-\gamma(\mathrm{ng} / \mathrm{mL})$ & $0.33 \pm 0.06$ & $4.68 \pm 0.41^{*}$ & $4.51 \pm 0.35$ & $3.24 \pm 0.22^{\#}$ & $2.67 \pm 0.27^{\#}$ & $2.54 \pm 0.15^{\#}$ \\
\hline
\end{tabular}

Data are means $\pm \mathrm{SD} ; \mathrm{n}=12$ per group. *, $\mathrm{P}<0.05$ vs. cont group;, $\mathrm{P}<0.05$ vs. DM group. $\mathrm{DM}$, diabetic model group.

A

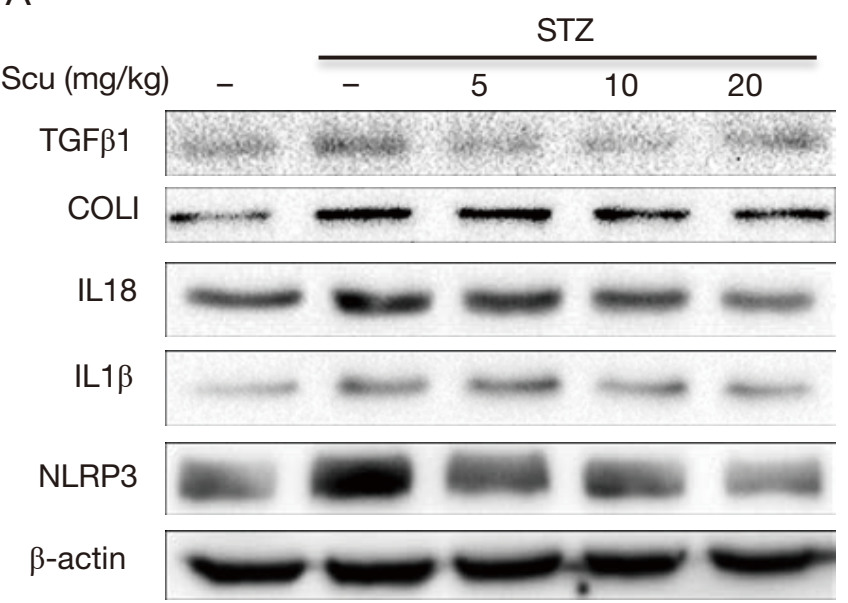

B

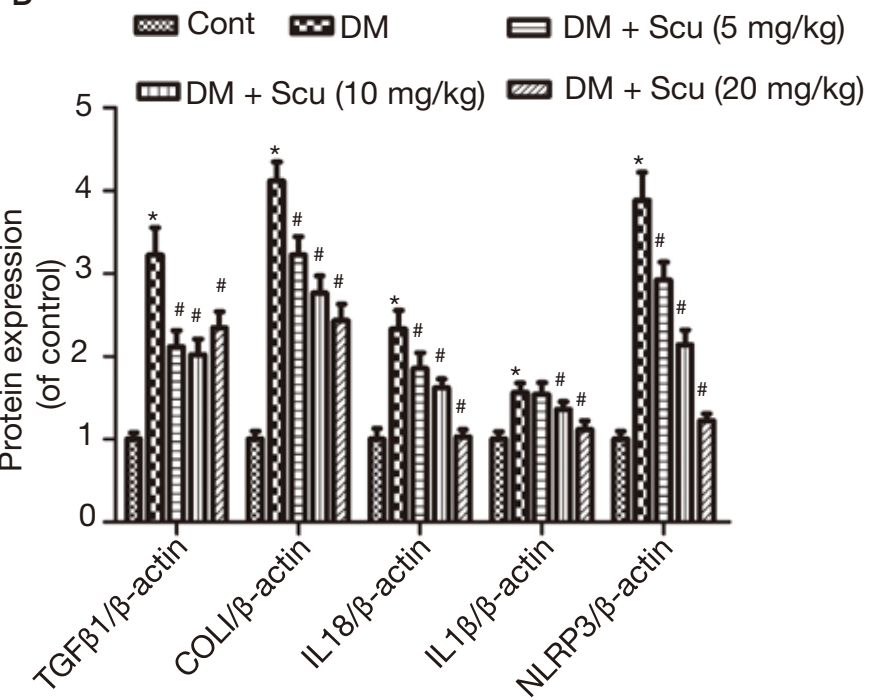

Figure 5 Effects of Scu on fibrosis and NLRP3 inflammasome-related protein expression in heart tissues. (A) The protein levels of TGF 31 , COL1, IL-1 $\beta$, IL-18, and NLRP3 in the myocardium were examined by western blot analysis. (B) Quantification of protein expression. Data are means $\pm \mathrm{SD} ; \mathrm{n}=3$ per group. *, $\mathrm{P}<0.05$ vs. control group; ${ }^{\#}, \mathrm{P}<0.05$ vs. $\mathrm{DM}$ group. 
A



B
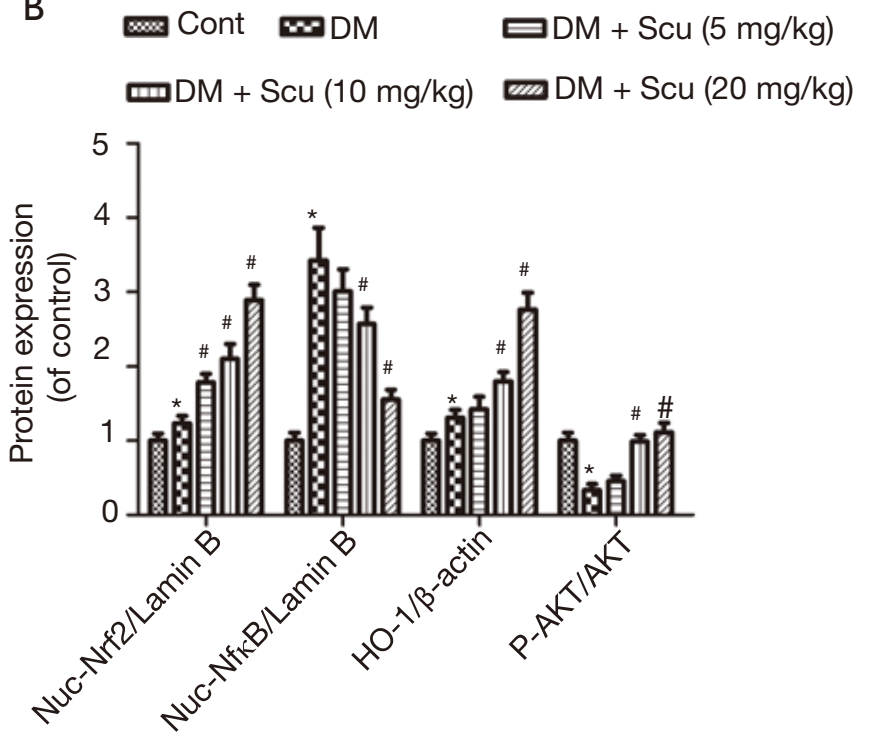

Figure 6 Involvement of Akt, Nrf2, and NfкB signallings in DM-induced cardiac dysfunction. (A) The protein levels of nucleus NF- $\kappa \mathrm{B}$, nucleus Nrf2, HO-1, p-AKT and AKT in the myocardium were examined by western blot analysis. (B) Quantification of protein expression. Data are means $\pm \mathrm{SD} ; \mathrm{n}=3$ per group. * $\mathrm{P}<0.05$ vs. control group; ${ }^{*}, \mathrm{P}<0.05$ vs. $\mathrm{DM}$ group.

First, we found that mice in DM group showed lower heart weight and body weight and higher heart/body weight ratio compared with control group. Then we evaluated heart function and M-mode echocardiography showed that LVVd, EF and FS markedly decreased in DM group, which suggested that the myocardial contractile function of mice was impaired after STZ injection. However, Scu treatment decreased heart/body weight ratio and increased myocardial contractile function by elevating levels of LVVd, EF and FS.

CK-MB, LDH, and cTnI are three important biochemical markers, which reflect the injury degree of heart disease (14). Levels of CK-MB, LDH, and cTnI in serum of mice increased significantly in DM group compared with control, which decreased in Scu treatment. HE staining proved that $\mathrm{Scu}$ alleviated pathological changes of heart tissues in diabetes mice. These results indicated that $\mathrm{Scu}$ attenuated heart injury of diabetic mice.

One of the important pathological structural changes in diabetes is myocardial fibrosis $(15,16)$. TGF- $\beta 1$ signaling pathway is activated by continuous of hyperglycemia and then increased the level of fibrotic markers in hearts of diabetic mice, including $\alpha$-SMA, Col I, and Col III (17). The increase of collagen level in left ventricular endomyocardial in diabetes patients may induce decrease of myocardial contractility by reducing EF (18). Inhibition of myocardial fibrosis is one important therapeutic strategy in DCM.
In our study, Masson staining showed that STZ injection induced myocardial fibrosis. Immunohistochemistry and western blot proved the activation of TGF- $\beta 1$ and deposition of Col I in heart tissues of mice in DM group. However, Scu could reduce the myocardial fibrosis and decreased levels of TGF- $\beta 1$ and deposition of Col I in heart tissues of mice, which indicated that Scu alleviated the fibrosis process in diabetic mice.

Cardiac inflammation plays an important role in the development of DCM. The level of proinflammatory cytokines (IL- $1 \beta$, TNF- $\alpha$, IL-18, IL-6, MCP- 1 and IFN- $\gamma$ ) increased significantly in DCM, and reducing inflammation can impede DCM development $(19,20)$. Previous studies have demonstrated that the NLRP3 inflammasome complex participates in the progress of cardiovascular diseases, including ischemic heart disease, atherosclerosis, and DCM $(19,21)$. Consistent with other studies, we found that STZ induced higher expression of the NLRP, IL-1 $\beta$, and IL-18 in heart tissues of diabetic mice. However, Scu treatment significantly inhibited the activation of the NLRP3 inflammasome and the release of proinflammatory cytokines. We also revealed that STZ induced an increase of the level of the nuclear translocation of NF- $\mathrm{KB}$, which inhibited by Scu treatment. These results indicated that Scu may reduce cardiac inflammation and activation of NLRP3 inflammasome by inhibiting nuclear NF- $\mathrm{\kappa B}$ translocation. 
A lot of studies have shown that the level of ROS increased in diabetes, and DCM is associated with oxidative stress (22). Recent studies proved that Scu provide antioxidant activities in various disease $(9,23,24)$. In our study, we found that Scu reduced oxidative stress in the heart tissues by decreasing levels of ROS and MDA and increasing activities of SOD, CAT and GSH-px. HO-1 is a rate-limiting enzyme that degrades heme (a potent oxidant) to bilirubin (which has antioxidant properties) (25). As an adaptive survival response, $\mathrm{HO}-1$ up-regulated in cells under oxidative stress. Previous studies showed that the expression of HO-1 is regulated by the Nrf2 signaling pathway (26). Nrf2 signaling has an important function in protecting cardiomyocyte from oxidative stress injury (27). Under normal conditions, Nrf2 is located in the cytoplasm and binds with Keap1. Nrf2 can be activated by a range of oxidative and electrophilic stimuli, including ROS, heavy metals, and certain disease processes. The activated Nrf2 is released from Keap1 and translocated to the nucleus, where it activates the transcription of target genes, such as HO-1 (28). In the present study, STZ exposure induced moderate activity of the Nrf2 signaling pathway and caused serious injury to cardiomyocyte. However, treatment with Scu significantly increased Nrf2 translocation, as well as the protein expression of $\mathrm{Nrf} 2$ target gene, HO-1, and their enzymatic activity. These results suggested that Scu may protect against DCM via triggering the activation of $\mathrm{Nrf2}$ / HO-1 signaling.

$\mathrm{PI} 3 \mathrm{~K} / \mathrm{AKT}$ signaling pathway plays an important role in cell survival. AKT activation could improve contractile function of heart and prevent the develop of DCM (29). Various studies found that PI3K/AKT could inhibit oxidative stress and inflammatory response via regulating Nrf2 and NF- $\kappa B(30,31)$. In our study, the decrease of p-AKT in cardiomyocytes in diabetic mice can be prevented by Scu treatment, indicating that PI3K/AKT may also participate the protecting effect of Scu on DCM.

\section{Conclusions}

The results of this study demonstrated that Scu reduced myocardial damage and exerted antifibrotic, antiinflammatory and antioxidant effects on diabetic mice. The molecular mechanism may be related with activation of AKT and Nrf2/HO-1 and inhibition of NF- $\kappa B / N L R P 3$ signaling pathway. The findings of our study elucidate the potential of Scu for treating DCM.

\section{Acknowledgments}

Funding: This study was supported by the National Natural Science Foundation of China (No. 81603334), CAMS Innovation Fund for Medical Sciences (CIFMS) (No. 2019-I2M-1-005), National key research and development program (No. 2018YFC1707408), and Key Laboratory of Chinese Academy of Medical Sciences (No. 2018PT35030).

\section{Footnote}

Data Sharing Statement: Available at http://dx.doi. org/10.21037/apm-19-516

Conflicts of Interest: All authors have completed the ICMJE uniform disclosure form (available at http://dx.doi. org/10.21037/apm-19-516). The authors have no conflicts of interest to declare.

Ethical Statement: The authors are accountable for all aspects of the work in ensuring that questions related to the accuracy or integrity of any part of the work are appropriately investigated and resolved. All experimental procedures and protocols were conducted in accordance with the American Physiological Society "Guiding Principles in the Care and Use of Animals" and were approved by the Laboratory Animal Ethics Committee of the Institute of Medicinal Plant Development, Peking Union Medical College (No. 20181016).

Open Access Statement: This is an Open Access article distributed in accordance with the Creative Commons Attribution-NonCommercial-NoDerivs 4.0 International License (CC BY-NC-ND 4.0), which permits the noncommercial replication and distribution of the article with the strict proviso that no changes or edits are made and the original work is properly cited (including links to both the formal publication through the relevant DOI and the license). See: https://creativecommons.org/licenses/by-nc-nd/4.0/.

\section{References}

1. Jia G, Whaley-Connell A, Sowers JR. Diabetic cardiomyopathy: a hyperglycaemia- and insulin-resistanceinduced heart disease. Diabetologia 2018;61:21-8.

2. Jin L, Zhang J, Deng Z, et al. Mesenchymal stem cells ameliorate myocardial fibrosis in diabetic cardiomyopathy via the secretion of prostaglandin E2. Stem Cell Res Ther 
2020;11:122.

3. Palomer X, Román-Azcona MS, Pizarro-Delgado J, et al. SIRT3-mediated inhibition of FOS through histone $\mathrm{H} 3$ deacetylation prevents cardiac fibrosis and inflammation. Signal Transduct Target Ther 2020;5:14.

4. Chen R, Sun G, Yang L, et al. Salvianolic acid B protects against doxorubicin induced cardiac dysfunction via inhibition of ER stress mediated cardiomyocyte apoptosis. Toxicol Res (Camb) 2016;5:1335-45.

5. Platnich JM, Muruve DA. NOD-like receptors and inflammasomes: A review of their canonical and noncanonical signaling pathways. Arch Biochem Biophys 2019;670:4-14.

6. Ratajczak MZ, Bujko K, Cymer M, et al. The Nlrp3 inflammasome as a "rising star" in studies of normal and malignant hematopoiesis. Leukemia 2020;34:1512-23.

7. Zhang $\mathrm{X}, \mathrm{Fu} \mathrm{Y,} \mathrm{Li} \mathrm{H,} \mathrm{et} \mathrm{al.} \mathrm{H} 3$ relaxin inhibits the collagen synthesis via ROS- and P2X7R-mediated NLRP3 inflammasome activation in cardiac fibroblasts under high glucose. J Cell Mol Med 2018;22:1816-25.

8. Xu LJ, Chen RC, Ma XY, et al. Scutellarin protects against myocardial ischemia-reperfusion injury by suppressing NLRP3 inflammasome activation. Phytomedicine 2020;68:153169.

9. Sun XP, Wan LL, Yang QJ, et al. Scutellarin protects against doxorubicin-induced acute cardiotoxicity and regulates its accumulation in the heart. Arch Pharm Res 2017;40:875-83.

10. Pan ZW, Zhang Y, Mei DH, et al. Scutellarin exerts its anti-hypertrophic effects via suppressing the $\mathrm{Ca} 2+-$ mediated calcineurin and CaMKII signaling pathways. Naunyn Schmiedebergs Arch Pharmacol 2010;381:137-45.

11. Mo J, Yang R, Li F, et al. Scutellarin protects against vascular endothelial dysfunction and prevents atherosclerosis via antioxidation. Phytomedicine 2018;42:66-74.

12. Chledzik S, Strawa J, Matuszek K, et al. Pharmacological Effects of Scutellarin, An Active Component of Genus Scutellaria and Erigeron: A Systematic Review. Am J Chin Med 2018;46:319-37.

13. Chen RC, Wang J, Yang L, et al. Protective effects of ginsenoside Re on lipopolysaccharide-induced cardiac dysfunction in mice. Food Funct 2016;7:2278-87.

14. Lin R, Duan J, Mu F, et al. Cardioprotective effects and underlying mechanism of Radix Salvia miltiorrhiza and Lignum Dalbergia odorifera in a pig chronic myocardial ischemia model. Int J Mol Med 2018;42:2628-40.

15. Wang Y, Li H, Li Y, et al. Coriolus versicolor alleviates diabetic cardiomyopathy by inhibiting cardiac fibrosis and NLRP3 inflammasome activation. Phytother Res 2019.

16. Li R, Liu Y, Shan YG, et al. Bailcalin Protects against Diabetic Cardiomyopathy through Keap1/Nrf2/AMPKMediated Antioxidative and Lipid-Lowering Effects. Oxid Med Cell Longev 2019;2019:3206542.

17. Liao HH, Zhu JX, Feng H, et al. Myricetin Possesses Potential Protective Effects on Diabetic Cardiomyopathy through Inhibiting IkappaBalpha/NFkappaB and Enhancing Nrf2/HO-1. Oxid Med Cell Longev 2017;2017:8370593.

18. Li K, Zhai M, Jiang L, et al. Tetrahydrocurcumin Ameliorates Diabetic Cardiomyopathy by Attenuating High Glucose-Induced Oxidative Stress and Fibrosis via Activating the SIRT1 Pathway. Oxid Med Cell Longev 2019;2019:6746907.

19. Yang F, Qin Y, Wang Y, et al. Metformin Inhibits the NLRP3 Inflammasome via AMPK/mTOR-dependent Effects in Diabetic Cardiomyopathy. Int J Biol Sci 2019;15:1010-9.

20. Li H, Shi Y, Wang X, et al. Piceatannol alleviates inflammation and oxidative stress via modulation of the Nrf2/HO-1 and NF-kappaB pathways in diabetic cardiomyopathy. Chem Biol Interact 2019;310:108754.

21. Yu SY, Dong B, Tang L, et al. LncRNA MALAT1 sponges miR-133 to promote NLRP3 inflammasome expression in ischemia-reperfusion injured heart. Int J Cardiol 2018;254:50.

22. Li L, Luo W, Qian Y, et al. Luteolin protects against diabetic cardiomyopathy by inhibiting NF-kappaBmediated inflammation and activating the Nrf2-mediated antioxidant responses. Phytomedicine 2019;59:152774.

23. Baluchnejadmojarad T, Zeinali H, Roghani M. Scutellarin alleviates lipopolysaccharide-induced cognitive deficits in the rat: Insights into underlying mechanisms. Int Immunopharmacol 2018;54:311-9.

24. Wang Z, Yu J, Wu J, et al. Scutellarin protects cardiomyocyte ischemia-reperfusion injury by reducing apoptosis and oxidative stress. Life Sci 2016;157:200-7.

25. Chen YH, Yet SF, Perrella MA. Role of heme oxygenase-1 in the regulation of blood pressure and cardiac function. Exp Biol Med (Maywood) 2003;228:447-53.

26. Chen RC, Sun GB, Wang J, et al. Naringin protects against anoxia/reoxygenation-induced apoptosis in $\mathrm{H} 9 \mathrm{c} 2$ cells via the Nrf2 signaling pathway. Food Funct 2015;6:1331-44.

27. Zhang HJ, Chen RC, Sun GB, et al. Protective effects of total flavonoids from Clinopodium chinense (Benth.) 
O. Ktze on myocardial injury in vivo and in vitro via regulation of Akt/Nrf2/HO-1 pathway. Phytomedicine 2018;40:88-97.

28. Habtemariam S. The Nrf2/HO-1 Axis as Targets for Flavanones: Neuroprotection by Pinocembrin, Naringenin, and Eriodictyol. Oxid Med Cell Longev 2019;2019:4724920.

29. Qi K, Zhong J. LncRNA HOTAIR improves diabetic cardiomyopathy by increasing viability of cardiomyocytes through activation of the PI3K/Akt pathway. Exp Ther

Cite this article as: $\mathrm{Xu} \mathrm{L}$, Chen $\mathrm{R}$, Zhang $\mathrm{X}$, Zhu Y, Ma $X$, Sun G, Sun X. Scutellarin protects against diabetic cardiomyopathy via inhibiting oxidative stress and inflammatory response in mice. Ann Palliat Med 2021;10(3):2481-2493. doi: 10.21037/apm-19-516
Med 2018;16:4817-4823.

30. Yang HL, Thiyagarajan V, Shen PC, et al. Anti-EMT properties of CoQ0 attributed to PI3K/AKT/NFKB/ MMP-9 signaling pathway through ROS-mediated apoptosis. J Exp Clin Cancer Res 2019;38:186.

31. Meng T, Fu S, He D, et al. Evodiamine Inhibits Lipopolysaccharide (LPS)-Induced Inflammation in BV-2 Cells via Regulating AKT/Nrf2-HO-1/NF-кB Signaling Axis. Cell Mol Neurobiol 2021;41:115-27. 